THE PROFESSIONAL DEVELOPMENT OF EMPLOYEES AND THEIR ROLE IN INCREASING PRODUCTIVITY AND DECISION-MAKING EFFECTIVENESS: AN APPLIED STUDY ON THE DUBAI POLICE CENTER

\title{
IN THE UNITED ARAB EMIRATES
}

\author{
ADNAN ALI HASSAN ALHOSANI \\ Faculty of Technology Management, University Tun Hussein Onn Malaysia
}

The study focused on the importance of human resource development and the training of employees in the Dubai Police stations in the United Arab Emirates. The research aimed to identify the concepts and theories of professional development and the importance of the human resource, which contributes to increasing productivity and making the right decision.

The researcher used the analytical descriptive approach, in addition to the field curriculum, through the design of the questionnaire, and distributed it to a sample of the 750 managers, distributed in five regions.

The use of the statistical package program (SPSS), as it is the most appropriate to reach accurate results, achieve what the researcher wants to achieve goals.

The study found that the importance of professional development in increasing the productivity of employees and employees, in addition to the fact that the training and qualification of managers would achieve good rates of good management

KEYWORDS: Professional Development, Delegation of Power, Decision Making, Dubai Police \& United Arab Emirates
\end{abstract}

Received: Jul 20, 2018; Accepted: Aug 20, 2018; Published: Dec 31, 2018; Paper Id.: IJHRMRFEB20192

\section{INTRODUCTION}

The study recommended the following recommendations:

- The attention of the police department councils with modern methods and plans and not relying on traditional plans that focus on the cognitive side

- Give the district councils more powers, especially in the decision-making in the security aspects.

- The need to give the councils of the department, the powers to nominate members of the Police Authority, to complete their studies and professional development, and requests for scientific leave.

1.1. The Importance of the Study

The importance of the study lies in its seriousness and its serious attempt to identify the role of professional development and training for employees in increasing productivity and making the right decision. The 
role of training and developing staff skills cannot be underestimated and lead to the right decision.

The current global transformations related to professional development and the development of staff skills in the United Arab Emirates lie in (transformation in the nature of knowledge, transformation into the knowledge society, transformation towards microclimate, and transformation into the knowledge economy) (Kashkash, 2014, p. 62).

\subsection{Problem of Study}

Professional development has a growing role in improving the performance of employees and managers, so the problem of research lies in answering the following main question:

What is the role of professional development in increasing employee productivity and decision making at Dubai Police City?

The main questions stem from the following sub-questions:

- What is the role of the police station managers in maintaining stability in Dubai?

- Is there a relationship between professional development and training managers and making the right decision?

- Did the Dubai Police Centers contribute to the development of Dubai financially and economically?

\subsection{Objectives of the Study}

The objectives that the study is trying to achieve are the following points:

- To recognize the concepts of professional development and its importance in making the appropriate decision.

- Identify the relationship of professional development of employees to productivity and make appropriate decision in the UAE government.

\subsection{Research Methodology (the Design of Research)}

The methodology used in this study is a quantitative approach based on the causal (explanatory) and correlation research strategy.

Quantitative research is subjective by observation and empirical data, which means that quantitative approach, is mainly concerned with evaluating the cause and effect of specific phenomena and then uses the collected data by empirical observation methods.

The data collected in a quantitative approach are analysed using mainly statistical methods. The reason to adopt a quantitative approach in this study is to support the researcher to get a better understanding using statistical tools in order to understand the relationships between the variables of the study.

Commonly, quantitative approach is widely used in social sciences and economics as well as marketing and human development. The following are the main steps for conducting the quantitative analysis:

- Variables Specification: Variables are concepts of varying levels of abstraction that are measured, manipulated, or controlled in a study.

- Formulating Research Hypotheses and Variables: In this step the hypotheses statements about two or more 

concepts or variables are specified.

- Selecting the Population and Sample: The population is the group of participants to be investigated according to the research questions and objectives. The sample refers to specific people within the population of the study from which data will be collected in order to verify the research hypothesis.

- The Questionnaire: In this step the questionnaire which is the main tool for collecting the primary data from the sample of the study will be designed according to the findings from the literature review and research framework. The items of the questionnaire are related to the variables of the study.

- Collecting Data: Data collection source is the participants in the survey, then using the questionnaire for collecting primary data collected from the participants for the purpose of analysis and conclude the findings.

- Analysing the Data: Statistical procedures are used to analyse the primary data and provide answers to the research question as well as verifying the hypotheses of the study.

- Findings and Conclusions: The researcher explains the results of the study and links them to the existing body of knowledge in the literature. The researcher then describes the implications of the study and suggests directions for further research in the same topic.

\subsection{Data Collection}

The questionnaire is a data collection instrument that consists of a set of questions (items) that request for very specific information or data, in order to compile information of the persons in question (participant).

The questionnaires are often designed for statistical analysis of responses from participants.

However, this is not the case always. The questionnaire is an affordable data collection instrument which does not require the same amount of effort in verbally or searching through the phone, and often have to identify the specific record answers in the data which makes it easy to assemble and organize then analyse.

However, these specific answers often cause frustration among those who answer is committed to the limits of those who answered that they could read the questions and answer them, so that the questionnaires may not be practical in some population groups.

In addition, some of the wording of the question in the questionnaires may pose a problem in getting the appropriate answer.

But questionnaires have major advantages over other data collection instruments, for example, it is cheaper and it requires less effort compared to verbal surveys like using telephone interviews, and often have standardized answers which are important in statically analysis Mellenbergh.

\section{GENERAL CONCEPTS IN HUMAN DEVELOPMENT}

There is no doubt that human capital cannot reduce its role and productivity compared to physical capital, so the fundamentals of sustainable economic development depend on the human being as the main source in conjunction with the other components, including: nature and its resources, minerals and renewable resources in the ground, technology and technology, and It is also necessary to say that development in the holistic sense must be carried out by man, for his benefit 
and for his sake, and that there is no value to it if it is not for the benefit of man (al Masri, 2016, p. 37).

Human development as a process requires a certain amount of creativity and development, and this needs the following conditions (al Masri, 2016, p. 35).

The existence of an independent and coherent country and an investigator of its national unity.

Political and security stability, there is no development in the face of political conflicts, wars, coups and internal disturbances.

Openness to the outside world to derive its strength and prosperity, and this is one of the determinants of the development of any society no matter how different economic components.

To raise the standard of living through greater job opportunities, better education, a distinct health level, and an interest in cultural values and human values.

The distribution of commodities to all members of society equally, such as food, housing, protection, security and justice.

The United Arab Emirates is one of the highest countries in the world in terms of human development indicators due to government investment in human resources and development, which can be seen from the objectives of government plans and programs. Intellectual capital has become one of the main sources of growth in the UAE and one of the pillars of the development process. Especially in the rapid transition of the knowledge economy, and one of its key indicators is the growth of human resources and their use of modern technological means and the development of their various skills.

Countries continue to view economic growth and development as a major policy and economic objective, and those without development find themselves lagging behind. The absence of development is one of the reasons for the political and security imbalances.

The revolutions in Eastern Europe and the former Soviet Union were caused by recession Economic growth and low rates of economic development, which are the most important factor in the economic success of countries in the long term (Samuelson and Nordhaus, 2006, p. 563).

The increase in the productivity of human capital is the central objective of enterprises, organizations and economies, regardless of their different structures and the size of their wealth and resources. Countries seek to increase the productivity of the human resource as the most important productive factor. (Ziara, 2014, pp. 66-68).

Abundance or Scarcity of Production Elements: This factor depends on the abundance and quality of productive elements, and on the extent of exploitation and the importance of these resources.

Demand Volume: The large increase in demand leads to an increase in value added, thus increasing labour productivity.

Technical or Technological Progress: labour productivity is the highest in economies that continuously take on all the causes of technological development.

Capital Intensity: The more capital used in the development of production, the greater the productivity.

Quality of labour: The productivity of the skilled worker is higher than that of the unskilled worker because the 
Economic and Social Institutions: The success of society in achieving a high level of economic progress and then in the level of productivity requires the provision of advanced social and political systems. The worker does not work in a vacuum, but works within a specific economic, political and social framework that takes into account their mutual interests.

Facility Management and Industrial Processes: One of the most important considerations in increasing production efficiency, according to many studies, is that the majority of production efficiency constraints are due to mismanagement and planning.

It can be said that the origin of development is the ability to satisfy the desires and needs of successive people, multiple and renewable as the human being is the key element of development, that saturation is closely linked to the existence of an active role of the state in various aspects of the economy, specifically in public policies favouring the poor and support programs of protection and security Social development dimensions (al radio, 2016, p. 2).

In other words, sustainable development must include macroeconomic policies in the fields of fiscal, monetary, trade and employment policies that tend towards justice in the redistribution of the material goods of the society, whether they relate to consumer goods or productivity. Therefore, there can be no value to the economy unless there is A true and just development is centered and its essence is human, human and human (al radee, 2016, p. 3).

Based on the above, an active role for the state and its institutions is the main guarantor for achieving the objectives of sustainable economic development approved by the United Nations 17 goals (al radee, 2016, p. 3).

Despite the many definitions of sustainable economic development, the researcher tends to mean that long-term economic policy aimed at achieving sustained economic growth, accompanied by a continuous increase in average per capita income over a long period of time (current generation and future generations). The average per capita income is the primary yardstick for measuring growth velocity and the extent of effort in a given society for another society.

This process is complex and multidimensional, with drastic changes in the social, behavioural, cultural, political and administrative structures along with increasing rates of economic growth, justice in the distribution and redistribution of national income and the eradication of absolute poverty in a society. Achieving the common human values (al radee, 2016, p. 4).

Satisfying the basic needs of individuals.

Self-realization and affirmation of humanity.

Freedom and choice.

United Arab Emirates governments have given increased attention to human investment as the main source of economic and social development. The UAE's philosophy is that "building factories is easier than building men. This is a fact that every householder should be aware of. The future, good and integrated preparation, to continue the process of good and giving and growth in the homeland "(al radee, 2016).

The trained and professional workers in the United Arab Emirates play a positive role in increasing productivity and making the right decision, as good governance is the means of good governance. 


\subsection{The Second Axes (Decision-Making)}

The study of Armbruster and Beckmann (2010) entitled "Business Environment, Managerial Strategies, And The Allocation Of Decision-Making Authorities In Swiss Firms" The allocation of decision-making authorities may be seen as the last link in a causal relationship starting from changes in environment and continuing to business strategy.

Changes in task complexity, which can be measured by the introduction of a diversification or an outsourcing strategy, were expected to result in a shift towards a more centralised or decentralised allocation of decision-making authorities.

Using nationally representative Swiss firm data, OLS, Propensity Score Matching as well as a combined matching and difference in differences approach in order to account for endogenous and unobserved heterogeneity were applied. Estimates using all three approaches show a highly significant positive impact of outsourcing on a decentralised decision rights assignment, whereas a diversification strategy yields no influence. The conclusion, therefore was that a lower delegation, risk due to a decline in complexity results in decentralised decision-making authorities in Swiss firms.

The study of Mitchell et al (2011), entitled, "Erratic Strategic Decisions: When And Why Managers were Inconsistent In Strategic Decision Making" While decision makers in organisations frequently make good decisions rooted in stable and consistent preferences, such consistency in outcomes was not always the case. In this study, they adopt a psychological perspective of judgment to investigate managers' erratic strategic decisions, which they define as a manager's inconsistent judgment that can shape the direction of the firm. In a study of 2,048 decisions made by 64 CEOs of technology firms, they examine how both metacognitive experience and perceptions of the external environment (hostility and dynamism) could affect the extent to which managers make erratic strategic decisions.

The results indicate that managers with greater metacognitive experience make less erratic strategic decisions. The results also indicate that in hostile environment managers make more erratic strategic decisions. But contrary to their expectations, in dynamic environment managers make less erratic strategic decisions. Similarly, hostility and dynamism interact in their effect on erratic strategic decisions in that the positive relationship between environmental hostility and erratic strategic decisions will be less positive for managers experiencing high environmental dynamism than those experiencing low environmental dynamism. These results have important implications for strategic decision-making research.

The study of Hogden et al (2013), entitled "Development of a model to guide decision making in amyotrophic lateral sclerosis multidisciplinary care" Patients with amyotrophic lateral sclerosis (ALS) face numerous decisions for symptom management and quality of life. Models of decision making in chronic disease and cancer care were insufficient for the complex and changing needs of patients with ALS.

The aim was to examine the question: how can decision making that was both effective and patient centred be enacted in ALS multidisciplinary care? The Setting and participants was Fifty-four respondents (32 health professionals, 14 patients and eight carers) from two specialized ALS multidisciplinary clinics participated in semi-structured interviews. Interviews were transcribed, coded and analysed thematically. They Comparison of stakeholder perspectives revealed six key themes of ALS decision making.

These were the decision-making process; patient centred focus; timing and planning; information sources; engagement with specialized ALS services; and access to non-specialized services. A model, embedded in the specialized 
The Professional Development of Employees and their Role in Increasing

Productivity and Decision-Making Effectiveness: An Applied Study on

the Dubai Police Center in the United Arab Emirates

ALS multidisciplinary clinic, was derived to guide patient decision making. The model was cyclic, with four stages: 'Participant Engagement'; 'Option Information'; 'Option Deliberation'; and 'Decision Implementation'. Finally, they found that Effective and patient centred decision making was enhanced by the structure of the specialised ALS clinic, which promotes patients' symptom management and quality of life goals. However, patient and carer engagement in ALS decision making was tested by the dynamic nature of ALS, and patient and family distress. Their model optimises patient centred decision making, by incorporating patients' cyclic decision-making patterns and facilitating carer inclusion in decision processes. Conclusions the model captures the complexities of patient centred decision making in ALS. The framework can assist patients and carers, health professionals, researchers and policymakers in this challenging disease environment.

The study of Vriens and Achterbergh (2013), entitled "Tools for Supporting Responsible Decision-Making?" assess the characteristics decision support tools should have in order to support "responsible decision-making". To this end, they first describe responsible decision making. They argue that responsibility relates to both the outcome and the process of decision making. On the basis of this description, they discuss which conditions should be in place so as to increase the possibility of responsible decision making. Next, they discuss the characteristics of tools supporting responsible decision-making in terms of their ability to support the realization of the required conditions for responsible decision-making. They use these characteristics to identify three types of tools: "responsible", "neutral", and "irresponsible" tools. They illustrate the assessment of the responsibility of support tools by looking at group model building.

The study of Weinberger et al (2014), entitled, "Towards a Framework for Untangling Complexity: The Inter professional Decision-Making Model for the Complex Patient" Decision making for the complex patient was challenging for doctors because of increased complexity, such as multiple co-morbidities and inter professionalism for which evidencebased literature and guidelines were currently lacking. The consequent uncertainty causes vagueness, threatening patient safety and the quality of care.

This article was motivated by the design science paradigm and describes the inter professional decision making model for the complex patient, namely, INDECO along with an example instantiation. Drawing on their experience in an intensive care unit of a tertiary hospital in Israel, the bi-dimensional view of this model includes the medical- and the inter professional perspective. A retrospective assessment of 3 case studies of complex patients was used for assessing the usefulness of INDECO in decision making. The study reported here draws support from relevant literature, including the information science, information systems, and the medical domains. The findings resonate with emerging research developments focusing on healthcare decision making.

The study of Yang et al (2014), entitled, "Stakeholders' Attributes, Behaviours, and Decision-Making Strategies in Construction Projects: Importance and Correlations in Practice" Project managers need to make decisions on how to balance competing claims between the different stakeholders in projects. Previous studies have suggested that the choice of decision-making strategies was highly related to stakeholders' attributes and behaviours in practice; however, limited studies have been conducted in the construction field to analyse the importance of stakeholders' attributes, behaviours, and decision-making strategies, and validate the correlations between the factors and decision-making strategies.

To analyse the underlying meanings of stakeholders' attributes, behaviours, and decision-making strategies from 
the practitioners' perspectives, and indicate the influence of stakeholder-related factors on decision-making strategies, an interview, questionnaire survey, and case study were adopted. Empirical studies suggest that three stakeholder attributes (power, urgency, and proximity), and four types of stakeholder behaviours (cooperative potential, competitive threat, opposite position, and neutral attitude) were perceived by the practitioners as important in dealing with stakeholder claims. Depending on stakeholders' salience levels and behaviour types, strategies of defense, compromise, or concession/adaptation were chosen and applied by project managers in practice. The findings can help project managers to proactively understand stakeholder performance, place emphasis on particular attributes and behaviours, and formulate appropriate schemes under different circumstances.

The study of Montiel (2015), entitled, "Out on A Limb: Appointing a Parenting Coordinator with DecisionMaking Authority in The Absence of a Statute or Rule" addresses the issue of whether a court may appoint a Parenting Coordinator (PC) with decision-making authority in the absence of a statute or court rule. The Article identifies possible sources of authority for the appointment of a PC with decision-making authority in a state with no authorising statute or court rule. It also provides a paradigm for constructing an appointment that allows for the benefits of Parenting Coordination but does not delegate decision-making authority to an extent that it would constitute an impermissible delegation of judicial authority.

The study of Uzonwanne (2015), entitled: "Leadership styles and decision-making models among corporate leaders in non-profit organisations in North America" This research seeks to study the relationship between leadership styles (selling, telling, delegating, and participating) of non-profit executives and their preferred decision-making models (rational, intuitive, dependent, spontaneous, and avoidant) used operationally in managing non-profit outfits striving to survive in turbulent economic situations. The General Decision Making Style Scale instrument and the Leader Behaviour Description Questionnaire were the instruments used for this study, and 109 out 500 randomly selected executives and leaders responded to the surveys. Data analyses used for this study were the Pearson correlation coefficient and the two way analysis of variance. Findings showed that there was a significant positive correlation between initiating structure leadership style and rational decision-making and between initiating structure leadership style and dependent decision.

Other findings also show a significant relationship between leadership style and the rational decision-making model, gender and leadership styles and the intuitive decision-making model among others. Findings may be useful in further understanding the placement of individuals with particular leadership styles in identified decision-making roles. For instance, multiple comparison results show that no matter what the demographic variables were, gender and age, corporate leaders who used the participating leadership style tend to use the dependent decision-making model.

\section{FOR DELEGATION OF AUTHORITY}

Delegation of Authority is an important tool that the Managers can use to reduce their pressure. The next sections will answer the questions of the search in detail which numbered from a to $\mathrm{c}$ using five fields to interpret the delegation of authority process for these different fields (decision making field, career growth field, status fields, Impact, and Selfefficacy).

\subsection{For Decision Making Field}

Table (1) indicates the mean of the response and the frequency for delegation of authority from a point view of Members of the Police Authority in Dubai, in the field of Decision Making (N (sample size) $=750$ ). 
Table 1: The Mean and the Frequency for Questions in Field of Decision Making

\begin{tabular}{|c|l|c|c|l|}
\hline $\mathbf{n}$ & \multicolumn{1}{|c|}{ Question } & $\begin{array}{c}\text { Mean of } \\
\text { Response }\end{array}$ & Frequency & \multicolumn{1}{|c|}{$\begin{array}{c}\text { Grade of Delegation } \\
\text { of Authority }\end{array}$} \\
\hline $\mathbf{1}$ & $\begin{array}{l}\text { Grant power to control police } \\
\text { programs. }\end{array}$ & 3.03 & 60.53 & High \\
\hline $\mathbf{2}$ & $\begin{array}{l}\text { Participate in the decision making } \\
\text { process for new programs }\end{array}$ & 2.93 & 58.59 & Moderate \\
\hline $\mathbf{3}$ & $\begin{array}{l}\text { Participate in the decision making } \\
\text { process for choosing new members }\end{array}$ & 2.86 & 57.20 & Moderate \\
\hline $\mathbf{4}$ & I can determine my work schedule & 3.03 & 60.51 & High \\
\hline $\mathbf{5}$ & $\begin{array}{l}\text { The head of the department takes my } \\
\text { own views on departmental affairs }\end{array}$ & 2.93 & 58.56 & Moderate \\
\hline $\mathbf{6}$ & $\begin{array}{l}\text { My colleagues in the department ask } \\
\text { for my advice }\end{array}$ & 2.86 & 57.25 & Moderate \\
\hline $\mathbf{7}$ & $\begin{array}{l}\text { Participation of the department in } \\
\text { decisions related to creative ideas }\end{array}$ & 3.03 & 60.51 & High \\
\hline $\mathbf{8}$ & $\begin{array}{l}\text { Participate in decisions related to the } \\
\text { budget of the department }\end{array}$ & 2.93 & 58.59 & Moderate \\
\hline $\mathbf{9}$ & $\begin{array}{l}\text { Making decisions in the area of the } \\
\text { police operation }\end{array}$ & 2.85 & 57.09 & Moderate \\
\hline $\mathbf{1 0}$ & I have control over my daily schedule & 3.03 & 60.51 & High \\
\hline $\mathbf{1 1}$ & $\begin{array}{l}\text { I have the ability to move towards my } \\
\text { favorite work }\end{array}$ & 2.93 & 58.56 & Moderate \\
\hline $\mathbf{1 2}$ & $\begin{array}{l}\text { I have the freedom to make decisions } \\
\text { about what to do }\end{array}$ & 2.87 & 57.31 & Moderate \\
\hline $\mathbf{T o t a l}$ & $\begin{array}{l}\text { Grade } \\
\text { Decision Making Field }\end{array}$ & $\mathbf{2 . 9 4}$ & $\mathbf{5 8 . 7 7}$ & Moderate \\
\hline
\end{tabular}

Maximum grade for response is (5).

From Table (1) we show that there was High grade of response to questions 1, 4, 7, and 10. And there was a Moderate grade of response to questions $2,3,5,6,8,9,11$, and 12 . It also indicates that the effect of delegation of authority on the decision-making strategy is a Moderate in the field of Decision making from a point of view for the police department in Dubai.

\subsection{For Career Growth Field}

Table (2) indicates the mean of the response and the frequency for delegation of authority from a point view of Members of the Police Authority in Dubai, in the field of Career Growth ( $\mathrm{N}=750)$.

Table 2: The Mean and the Frequency for Questions in Field of Career Growth

\begin{tabular}{|c|l|c|c|l|}
\hline $\mathbf{n}$ & \multicolumn{1}{|c|}{ Question } & $\begin{array}{c}\text { Mean of } \\
\text { Response }\end{array}$ & Frequency & \multicolumn{1}{|c|}{$\begin{array}{c}\text { Delegation of } \\
\text { Authority }\end{array}$} \\
\hline $\mathbf{1}$ & $\begin{array}{l}\text { I work in an appropriate professional } \\
\text { environment }\end{array}$ & 3.02 & 60.32 & High \\
\hline $\mathbf{2}$ & $\begin{array}{l}\text { Professionally employed by the Head } \\
\text { of Department }\end{array}$ & 2.93 & 58.64 & Moderate \\
\hline $\mathbf{3}$ & $\begin{array}{l}\text { I have the opportunity to grow } \\
\text { professionally }\end{array}$ & 2.86 & 57.23 & Moderate \\
\hline $\mathbf{4}$ & $\begin{array}{l}\text { Get a chance for continuous learning } \\
\text { (participation in conferences, } \\
\text { courses,... etc.) }\end{array}$ & 3.02 & 60.40 & High \\
\hline $\mathbf{5}$ & $\begin{array}{l}\text { I have the opportunity to cooperate } \\
\text { with members of the department }\end{array}$ & 2.92 & 58.48 & Moderate \\
\hline
\end{tabular}




\begin{tabular}{|c|l|c|c|l|}
\hline $\mathbf{6}$ & $\begin{array}{l}\text { I think my capabilities and abilities are } \\
\text { investing properly }\end{array}$ & 2.86 & 57.15 & Moderate \\
\hline $\mathbf{7}$ & $\begin{array}{l}\text { I receive a good statement about the } \\
\text { efficiency of my performance }\end{array}$ & 3.02 & 60.45 & High \\
\hline $\mathbf{8}$ & $\begin{array}{l}\text { Take into account the interest of } \\
\text { citizens who violate the professional } \\
\text { development }\end{array}$ & 2.93 & 58.56 & Moderate \\
\hline $\mathbf{9}$ & $\begin{array}{l}\text { I think I have the opportunity to grow } \\
\text { by working daily with dissenting } \\
\text { citizens }\end{array}$ & 2.86 & 57.15 & Moderate \\
\hline $\mathbf{1 0}$ & $\begin{array}{l}\text { I think I was able to develop } \\
\text { psychologically in the field of police } \\
\text { research }\end{array}$ & 3.02 & 60.43 & High \\
\hline $\begin{array}{c}\text { Total } \\
\text { Grade }\end{array}$ & $\quad$ Career Growth field & $\mathbf{2 . 9 4}$ & $\mathbf{5 8 . 8 8}$ & Moderate \\
\hline
\end{tabular}

Maximum grade for response is (5).

From Table (2) we show that there was High grade of response to questions 1, 4, 7, and 10. And there was a Moderate grade of response to questions 2, 3, 5, 6, 8, and 9. It also indicates that the effect of functionality of the organization to the decision-making strategy is a Moderate in the field of Career Growth from a point of view for the police department in Dubai.

\subsection{For Status Field}

Table (3) indicates the mean of the response and the frequency for delegation of authority from a point view of Members of the Police Authority in Dubai, in field of status (N (sample size) $=750$ ).

Table 3: The Mean and the Frequency for Questions in Field of Status

\begin{tabular}{|c|l|c|c|l|}
\hline $\mathbf{n}$ & \multicolumn{1}{|c|}{ Question } & $\begin{array}{c}\text { Mean of } \\
\text { Response }\end{array}$ & Frequency & \multicolumn{1}{|c|}{$\begin{array}{c}\text { Delegation of } \\
\text { Authority }\end{array}$} \\
\hline $\mathbf{1 1}$ & $\begin{array}{l}\text { I think I have the respect of my } \\
\text { colleagues in the department }\end{array}$ & 2.92 & 58.48 & Moderate \\
\hline $\mathbf{1 2}$ & $\begin{array}{l}\text { I think I am an active member of } \\
\text { the department }\end{array}$ & 2.86 & 57.23 & Moderate \\
\hline $\mathbf{1 3}$ & $\begin{array}{l}\text { I have the support of my } \\
\text { colleagues in the department }\end{array}$ & 3.02 & 60.35 & High \\
\hline $\mathbf{1 4}$ & $\begin{array}{l}\text { I have a good knowledge in my } \\
\text { field }\end{array}$ & 2.92 & 58.43 & Moderate \\
\hline $\mathbf{1 5}$ & $\begin{array}{l}\text { My colleagues tell me that I am } \\
\text { good at what I do in the } \\
\text { department }\end{array}$ & 2.85 & 57.04 & Moderate \\
\hline $\mathbf{1 6}$ & $\begin{array}{l}\text { I am satisfied with the nature of } \\
\text { the work I do in the department }\end{array}$ & 3.02 & 60.32 & High \\
\hline $\mathbf{1 7}$ & $\begin{array}{l}\text { I feel proud when I tell others that } \\
\text { I work in this place }\end{array}$ & 2.91 & 58.27 & Moderate \\
\hline $\begin{array}{l}\text { Total } \\
\text { Grade }\end{array}$ & Status field & $\mathbf{2 . 9 3}$ & $\mathbf{5 8 . 5 9}$ & Moderate \\
\hline
\end{tabular}

Maximum grade for response is (5).

From Table (3) we show that there was High grade of response to questions 13 and 16. And there was a Moderate grade of response to questions $11,12,14,15$, and 17. It also indicates that the effect of functionality of the organization to the decision-making strategy is a Moderate in field of status from a point of view ofthe police department in Dubai. 


\subsection{For Self-Efficacy Field}

Table (4) indicates the mean of the response and the frequency for delegation of authority from a point view of Members of the Police Authority in Dubai, in the field of Self-efficacy $(\mathrm{N}=750)$.

Table 4: The Mean and the Frequency for Questions in Field of Self-Efficacy

\begin{tabular}{|c|l|c|c|l|}
\hline $\mathbf{n}$ & \multicolumn{1}{|c|}{ Question } & $\begin{array}{c}\text { Mean of } \\
\text { Response }\end{array}$ & Frequency & \multicolumn{1}{|c|}{$\begin{array}{c}\text { Delegation of } \\
\text { Authority }\end{array}$} \\
\hline $\mathbf{1 8}$ & I think I help citizens to be good in society & 2.86 & 57.12 & Moderate \\
\hline $\mathbf{1 9}$ & I have authorized citizens with some tasks & 3.02 & 60.37 & High \\
\hline $\mathbf{2 0}$ & $\begin{array}{l}\text { Participate in important problems for } \\
\text { citizens }\end{array}$ & 2.92 & 58.45 & Moderate \\
\hline $\mathbf{2 1}$ & I see citizens getting better & 2.86 & 57.12 & Moderate \\
\hline $\mathbf{2 2}$ & $\begin{array}{l}\text { I imagine that I am capable of bringing } \\
\text { positive change to citizens }\end{array}$ & 3.01 & 60.24 & High \\
\hline $\mathbf{2 3}$ & $\begin{array}{l}\text { I am interested in developing and } \\
\text { improving the performance of my } \\
\text { department }\end{array}$ & 2.92 & 58.32 & Moderate \\
\hline $\mathbf{2 4}$ & $\begin{array}{l}\text { I think I'm positive about what I'm doing } \\
\text { towards my department }\end{array}$ & 2.86 & 57.23 & Moderate \\
\hline $\begin{array}{c}\text { Total } \\
\text { Grade }\end{array}$ & Self-Efficacy Field & $\mathbf{2 . 9 2}$ & $\mathbf{5 8 . 4 1}$ & Moderate \\
\hline
\end{tabular}

Maximum grade for response is (5).

From Table (4.2), (4.3), and (4.4) we show that there was High grade of response to questions 19 and 22. And there was a Moderate grade of response to questions 18, 20, 21, 23, and 24. It also indicates that the effect of functionality of the organization to the decision-making strategy is a Moderate in the field of Self-efficacy from a point of view for the police department in Dubai.

From tables (4) we find that the effect of functionality of the organization on the decision-making strategy has a Moderate response, where it is Moderate for each field (Career growth, Status, and Self-efficacy).

Table 4: Summary of the Effect of Functionality of the Organization on the Decision-Making Strategy

\begin{tabular}{|c|l|c|c|l|}
\hline $\mathbf{n}$ & \multicolumn{1}{|c|}{ Field } & Mean & Frequency & $\begin{array}{c}\text { Delegation } \\
\text { of Authority }\end{array}$ \\
\hline $\mathbf{1}$ & Career Growth field & 2.94 & 58.88 & Moderate \\
\hline $\mathbf{2}$ & Status field & 2.93 & 58.59 & Moderate \\
\hline $\mathbf{3}$ & Self-efficacy field & 2.92 & 58.41 & Moderate \\
\hline $\begin{array}{c}\text { Total } \\
\text { Grade }\end{array}$ & $\begin{array}{l}\text { The effect of functionality of the } \\
\text { organization on the decision- } \\
\text { making strategy }\end{array}$ & $\mathbf{2 . 9 3}$ & $\mathbf{5 8 . 4 1}$ & Moderate \\
\hline
\end{tabular}

Maximum grade for response is (5).

\subsection{For Impact Field}

Table (5) indicates the mean of the response and the frequency for delegation of authority from a point view of Members of the Police Authority in Dubai, in field of Impact $(\mathrm{N}=750)$. 
Table 5: The Mean and the Frequency for Questions in Field of Impact

\begin{tabular}{|c|l|c|c|l|}
\hline $\mathbf{n}$ & \multicolumn{1}{|c|}{ Question } & $\begin{array}{c}\text { Mean of } \\
\text { response }\end{array}$ & Frequency & \multicolumn{1}{c|}{$\begin{array}{c}\text { Delegation of } \\
\text { Authority }\end{array}$} \\
\hline $\mathbf{1}$ & $\begin{array}{l}\text { I think I have the ability to accomplish } \\
\text { things }\end{array}$ & 3.02 & 60.43 & High \\
\hline $\mathbf{2}$ & Participate in the development section & 2.92 & 58.45 & Moderate \\
\hline $\mathbf{3}$ & $\begin{array}{l}\text { I think I have a positive effect in my } \\
\text { department }\end{array}$ & 2.85 & 56.99 & Moderate \\
\hline $\mathbf{4}$ & $\begin{array}{l}\text { Leave a good impact to the citizens in the } \\
\text { department }\end{array}$ & 3.01 & 60.24 & High \\
\hline $\mathbf{5}$ & $\begin{array}{l}\text { I help citizens to do useful work that serves } \\
\text { the community }\end{array}$ & 2.91 & 58.29 & Moderate \\
\hline $\mathbf{6}$ & $\begin{array}{l}\text { I am keen to participate in the various } \\
\text { activities of the department }\end{array}$ & 2.86 & 57.17 & Moderate \\
\hline $\mathbf{7}$ & $\begin{array}{l}\text { I have the ability to make decisions about } \\
\text { my body }\end{array}$ & 3.01 & 60.29 & High \\
\hline $\mathbf{8}$ & $\begin{array}{l}\text { I realized that I had the opportunity to } \\
\text { influence my colleagues in the department }\end{array}$ & 2.92 & 58.43 & Moderate \\
\hline $\begin{array}{c}\text { Total } \\
\text { Grade }\end{array}$ & Impact field & $\mathbf{2 . 9 4}$ & $\mathbf{5 8 . 7 9}$ & Moderate \\
\hline
\end{tabular}

From Table (5) we show that there was High grade of response to questions 1, 4 and 7. And there was a Moderate grade of response to questions 2, 3, 5, 6 and 8. It also indicates that the employees' performance (scientific level, experience and efficiency) mediates the relationship between the delegation of authority and decision-making process is a Moderate in field of Impact from a point of view for the police department in Dubai.

\subsection{Summary of Delegation of Authority}

From the tables we find that the delegation of authority has a Moderate response, where it is Moderate for each field (Decision making field, Career Growth field, Status field, Self-efficacy field, and Impact field).

Table 6: Summary of the Delegation of Authority at different Fields

\begin{tabular}{|c|l|l|l|l|}
\hline $\mathbf{n}$ & \multicolumn{1}{|c|}{ Field } & Mean & Frequency & $\begin{array}{c}\text { Delegation } \\
\text { of Authority }\end{array}$ \\
\hline $\mathbf{1}$ & Decision making field & 2.94 & 58.77 & Moderate \\
\hline $\mathbf{2}$ & Career Growth field & 2.94 & 58.88 & Moderate \\
\hline $\mathbf{3}$ & Status field & 2.93 & 58.59 & Moderate \\
\hline $\mathbf{4}$ & Self-efficacy field & 2.92 & 58.41 & Moderate \\
\hline $\mathbf{5}$ & Impact field & 2.94 & 58.79 & Moderate \\
\hline Total Grade & $\begin{array}{c}\text { The delegation of } \\
\text { Authority }\end{array}$ & $\mathbf{2 . 9 3}$ & $\mathbf{5 8 . 6 9}$ & Moderate \\
\hline
\end{tabular}

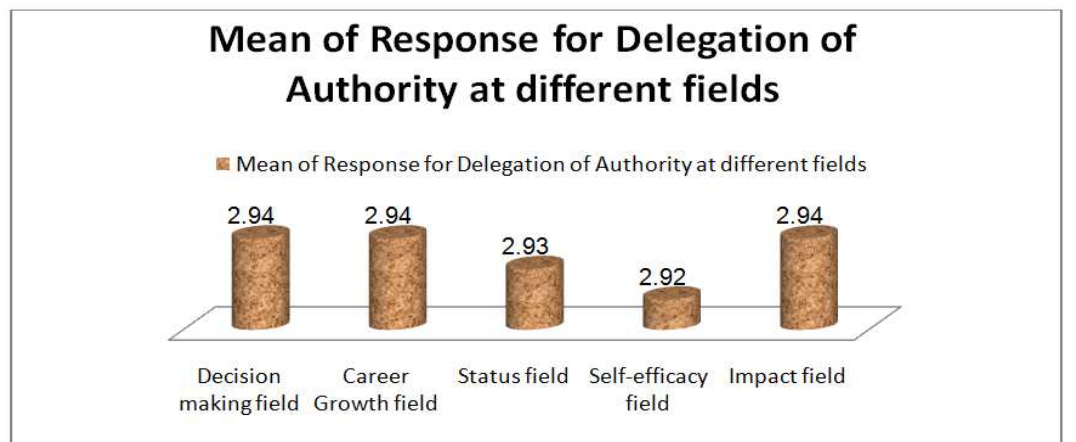

Figure 1: Mean of Response for Delegation of Authority at Different Fields 
From figure (1) we show that the mean response for delegation of authority is equal in fields (Decision Making,

Career growth, and Impact), and it is of lower value in the self - efficacy field.

\subsection{For Police Tasks Field}

Table (7) indicates the mean of the response and the frequency for Decision making from a point view of Members of the Police Authority in Dubai, in the field of police tasks $(\mathrm{N}=750)$.

Table 7: The Mean and the Frequency for Questions in Field of Police Tasks

\begin{tabular}{|c|l|c|c|l|}
\hline $\mathbf{n}$ & \multicolumn{1}{|c|}{ Question } & \multicolumn{1}{|c|}{$\begin{array}{c}\text { Mean of } \\
\text { Response }\end{array}$} & Frequency & \multicolumn{1}{|c|}{$\begin{array}{c}\text { Delegation of } \\
\text { Authority }\end{array}$} \\
\hline $\mathbf{1}$ & $\begin{array}{l}\text { The department proposes the } \\
\text { development of police plans and } \\
\text { programs }\end{array}$ & 2.86 & 57.25 & Moderate \\
\hline $\mathbf{2}$ & $\begin{array}{l}\text { The department contributes to solving the } \\
\text { problems of citizens }\end{array}$ & 3.02 & 60.32 & High \\
\hline $\mathbf{3}$ & $\begin{array}{l}\text { The department seeks to develop the } \\
\text { performance of the working members }\end{array}$ & 2.92 & 58.40 & Moderate \\
\hline $\mathbf{4}$ & $\begin{array}{l}\text { The department determines its need of } \\
\text { special tools and weapons to be secured in } \\
\text { the warehouse }\end{array}$ & 2.86 & 57.28 & Moderate \\
\hline $\mathbf{5}$ & $\begin{array}{l}\text { The department proposes using modern } \\
\text { methods to deal with citizens }\end{array}$ & 3.02 & 60.43 & High \\
\hline $\mathbf{6}$ & $\begin{array}{l}\text { The department studies scientific research } \\
\text { projects for working members }\end{array}$ & 2.92 & 58.43 & Moderate \\
\hline $\mathbf{7}$ & $\begin{array}{l}\text { The department determines its need for } \\
\text { operational means }\end{array}$ & 2.85 & 57.04 & Moderate \\
\hline $\mathbf{8}$ & $\begin{array}{l}\text { The Section Council examines and } \\
\text { analyzes crimes }\end{array}$ & 3.01 & 60.27 & High \\
\hline $\mathbf{9}$ & $\begin{array}{l}\text { The department is composed of } \\
\text { committees of its members to resolve } \\
\text { issues in the surrounding society }\end{array}$ & 2.92 & 58.48 & Moderate \\
\hline $\begin{array}{l}\text { Total } \\
\mathbf{G r a d e}\end{array}$ & $\begin{array}{l}\text { Police Tasks Field } \\
\mathbf{n}\end{array}$ & $\mathbf{2 . 9 3}$ & $\mathbf{5 8 . 6 5}$ & Moderate \\
\hline
\end{tabular}

Maximum grade for response is (5).

From Table (7) we show that there was High grade of response to questions 2, 5, and 8. And there was a Moderate grade of response to questions $1,3,4,6,7$ and 9. It also indicate that the delegation of authority, the decision-making process, the functionality of the organization and employees' performance are correlated in a theoretical model is Moderate in field of police tasks from a point of view for police department in Dubai.

\subsection{Summary of Decision Making}

From tables we find that the delegation of authority, the decision-making process, the functionality of the organization and employees' performance are correlated in a theoretical model has a Moderate response, where it is Moderate for each field (police tasks, Administrative tasks, and Exercise decision-making). 
Table 8: Summary of the Decision Making at Different Fields

\begin{tabular}{|c|c|c|c|l|}
\hline $\mathbf{n}$ & Field & Mean & Frequency & $\begin{array}{c}\text { Delegation of } \\
\text { Authority }\end{array}$ \\
\hline $\mathbf{1}$ & police tasks field & 2.93 & 58.65 & Moderate \\
\hline $\mathbf{2}$ & Administrative tasks field & 2.93 & 58.62 & Moderate \\
\hline $\mathbf{3}$ & $\begin{array}{c}\text { Exercise decision-making } \\
\text { field }\end{array}$ & 2.93 & 58.58 & Moderate \\
\hline $\begin{array}{c}\text { Total } \\
\text { Grade }\end{array}$ & The Decision Making & $\mathbf{2 . 9 3}$ & $\mathbf{5 8 . 4 1}$ & Moderate \\
\hline
\end{tabular}

\section{Mean of Response for Decision Making at different fields}

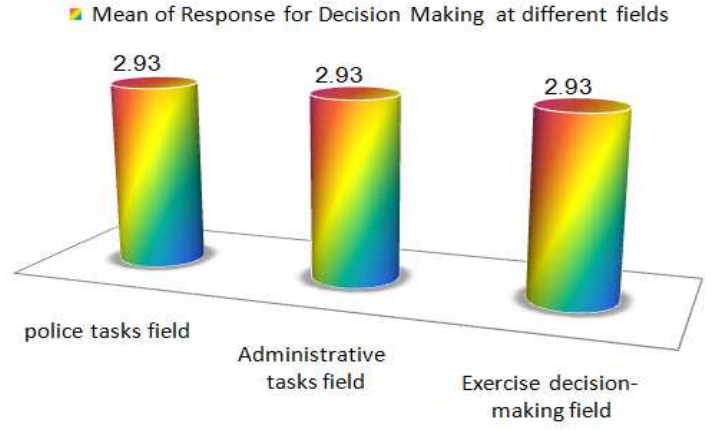

Figure 2: Mean of Response Decision Making at Different Fields

From figure (2) we show that the mean response for Decision Making is equal in fields (Police tasks, Administrative tasks, and Exercise decision making).

\subsection{For All Independent Variables Simmiltiouneously}

Table 9: MANOVA Table Results for Indicating the Significance Difference in of Authority and Decision Making which Related to all Independent Variables

\begin{tabular}{|l|l|c|c|c|c|c|}
\hline \multicolumn{2}{|c}{ Effect } & Value & F & Hypothesis df & Error df & Sig. \\
\hline \multirow{4}{*}{ Intercept } & Pillai's Trace & .994 & 3723.811 & 7.000 & 148.000 & .000 \\
\cline { 2 - 7 } & Wilks' Lambda & .006 & 3723.811 & 7.000 & 148.000 & .000 \\
\cline { 2 - 7 } & Hotelling's Trace & 176.126 & 3723.811 & 7.000 & 148.000 & .000 \\
\cline { 2 - 7 } & Roy's Largest Root & 176.126 & 3723.811 & 7.000 & 148.000 & .000 \\
\hline \begin{tabular}{l} 
Delegation of $\begin{array}{l}\text { Authority } \\
\text { and Decision } \\
\text { Making }\end{array}$ \\
\cline { 2 - 7 }
\end{tabular} & Pillai's Trace & 5.560 & .999 & 4165.000 & 1078.000 & .509 \\
\cline { 2 - 7 } & Wilks' Lambda & .000 & 1.002 & 4165.000 & 1050.805 & .488 \\
\cline { 2 - 7 } & Hotelling's Trace & 28.624 & 1.005 & 4165.000 & 1024.000 & .461 \\
\cline { 2 - 7 } & Roy's Largest Root & 6.417 & 1.661 & 595.000 & 154.000 & .000 \\
\hline
\end{tabular}

Significance level at $\alpha=0.05$

From table (9) we find that there was not found any statistically significant difference in police department in point of view for police men that found in Dubai at level $\alpha=0.05$ in Delegation of Authority and Decision Making related to all independent variables.

\subsection{Test of Normality of Delegation of Authority and Decision Making}

This section combine between the two variables Delegation of Authority and decision-making to explore its statistics such as (Mean, Median, variance, Skewness, and Kurtosis) to check its normality in order to use it in the statistical analysis. 
Table 10: Statistics Table for Delegation of Authority and Decision Making Variable

\begin{tabular}{|c|c|c|}
\hline \multirow{2}{*}{$\mathbf{N}$} & Valid & 1500 \\
\hline & Missing & o \\
\hline \multicolumn{2}{|c|}{ Mean } & 2.9000 \\
\hline \multicolumn{2}{|c|}{ Median } & 2.9545 \\
\hline \multicolumn{2}{|c|}{ Variance } & .104 \\
\hline \multicolumn{2}{|c|}{ Skewness } & $-.388-$ \\
\hline \multicolumn{2}{|c|}{ Std. Error of Skewness } & .063 \\
\hline \multicolumn{2}{|c|}{ Kurtosis } & $-.036-$ \\
\hline \multicolumn{2}{|c|}{ Std. Error of Kurtosis } & .126 \\
\hline
\end{tabular}

The next table indicate that the variable Delegation of Authority and Decision Making not distributed normally, where the value of Kolmogorov-Smirnov test reach to 0.146 with 0.000 significance level. This is means that the Mean and the Median of the variable are different.

Table 11: Test of Normality for Delegation of Authority and Decision Making Variable

\begin{tabular}{|l|c|c|c|c|c|c|}
\hline & \multicolumn{3}{|c|}{ Kolmogorov-Smirnov } & \multicolumn{3}{c|}{ Shapiro-Wilk } \\
\cline { 2 - 7 } & Statistic & df & Sig. & Statistic & df & Sig. \\
\hline $\begin{array}{l}\text { Delegation of Authority } \\
\text { and decision making }\end{array}$ & .146 & 1500 & .000 & .950 & 1500 & .000 \\
\hline
\end{tabular}
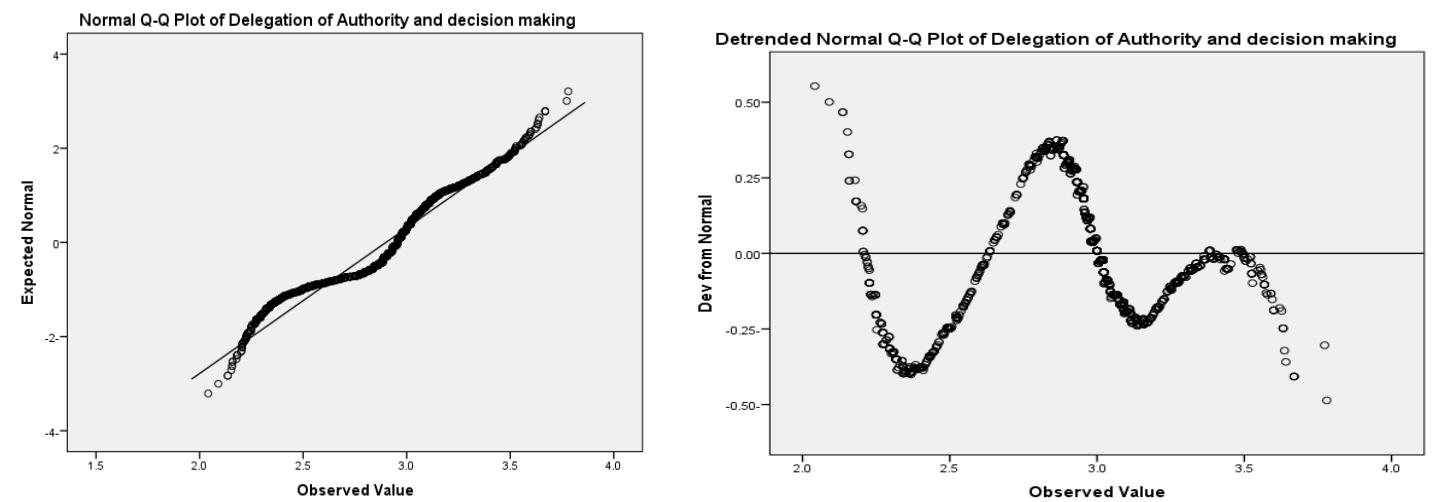

Figure 3: Normal and Determinant Normal Q-Q Plot of Delegation of Authority and Decision Making

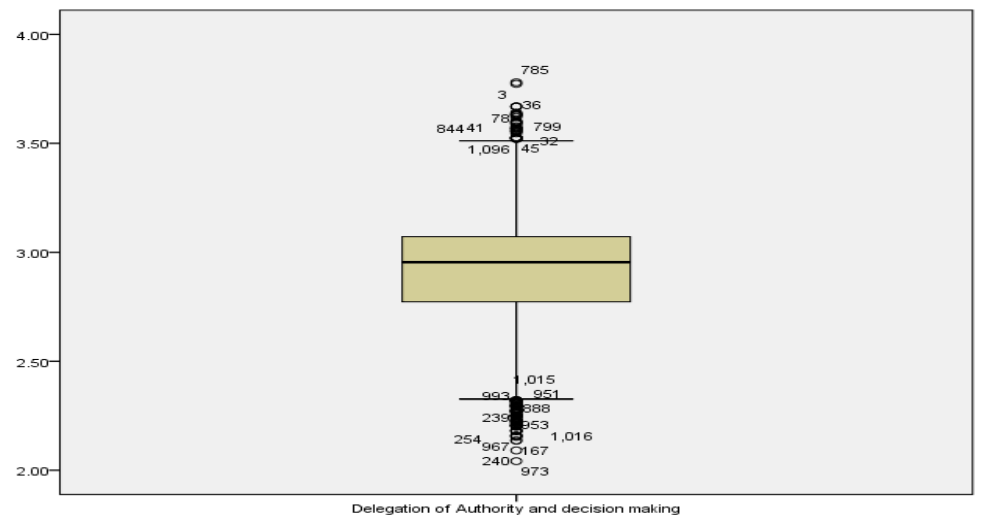

Figure 4: Box Plot of Delegation of Authority and Decision Making Variable

\subsection{Mediate of Employees' Performance}

For all variables we assumed that the null hypothesis is the Employees' performance variables equal the Median 
of the variable Delegation of Authority and Decision Making, and the alternative hypothesis is the Employees' performance variables not equal the Median of the variable Delegation of Authority and Decision Making. The p-value of this test reach to $0.298>0.05$ which means that we will accept the null hypothesis which indicate that the Employees' performance variables equal the Median of the variable Delegation of Authority and Decision Making with the level of significance $5 \%$.

Table 12: Test of Normality for Delegation of Authority and Decision Making Variable

\begin{tabular}{|l|c|c|c|c|c|c|}
\hline & \multicolumn{6}{|c|}{ Test Value = 2.9545 (Median) } \\
\hline & $\mathbf{N}$ & Mean & $\begin{array}{c}\text { Std. } \\
\text { Deviation }\end{array}$ & $\begin{array}{c}\text { Std. Error } \\
\text { Mean }\end{array}$ & t-test & p-value \\
\hline $\begin{array}{l}\text { Employees' } \\
\text { performance }\end{array}$ & 750 & 2.9393 & 0.39921 & 0.01458 & -1.040 & 0.298 \\
\hline
\end{tabular}

As we have seen in table (4.73) The p-value of this test reach to $0.298>0.05$ which means that we will accept the null hypothesis which indicate that the Employees' performance variables equal the Median of the variable Delegation of Authority and Decision Making with level of significance 5\%.

\section{RESULTS}

The study reached a number of theoretical and quantitative findings, including a direct impact of delegation of authority at the Dubai Police Station to make the right decision.

Which in turn contributed to improving the performance of employees in Dubai Police stations. There is a strong relationship between staff performance, delegation of authority and the most appropriate decision-making capacity.

The Dubai Police also witnessed significant developments in Dubai, particularly in the area of economic development.

\section{RECOMMENDATIONS}

The attention of the police department councils with modern methods and plans and not relying on traditional plans that focus on the cognitive side.

Give the district councils more powers, especially in the decision-making in the security aspects.

The need to give the councils of departments the powers to nominate members of the Police Authority to complete their studies and professional development and requests for scientific leave.

The necessity of granting the police department councils the authority to nominate members of the Police Authority to attend scientific conferences and seminars outside of Dubai, in order to motivate members of the Police Authority to learn about new information and new experiences that will benefit them in security, scientific research and the development of the work and performance of departments and boards.

The heads of departments should take into account the allocation of time on the subjects to be discussed and make decisions or recommendations on them in a suitable manner for each subject.

The adoption of heads of departments able to deal with the language of planning, thought and creativity in a sophisticated scientific and renewable. 
1. Armbruster, K., and Beckmann, M. (2010) "Business environment, managerial strategies, and the allocation of decisionmaking authorities in Swiss firms" A publication of the Center of Business and Economics, 6, 1-33.

2. Mitchell, J., Shepherd, D., Sharfman, M. (2011) "Erratic Strategic Decisions: When and Why Managers were Inconsistent in Strategic Decision Making" Strategic Management Journal, 32, 683-704.

3. Hogden, A., Greenfield, D., and Nugus, P. (2013) "Development of a model to guide decision making in amyotrophic lateral sclerosis multidisciplinary care" John Wiley \& Sons Ltd Health Expectations.

4. Vriens, D., and Achterbergh, J. (2013) "Tools for Supporting Responsible Decision-Making?" Systems Research and Behavioral Science, (wileyonlinelibrary.com).

5. Weinberger, H., Cohen, J., Tadmor, B., and Singer, P. (2014) "Towards a Framework for Untangling Complexity: The Inter professional Decision-Making Model for the Complex Patient" Journal of the Association for Information Science and Technology, 66, 392-407.

6. Yang, R., Wang, Y., and Jin, X. (2014) "Stakeholders' Attributes, Behaviours, and Decision-Making Strategies in Construction Projects: Importance and Correlations in Practice" Project Management Journal, 74-90.

7. Montiel, J. (2015) "Out On A Limb: Appointing A Parenting Coordinator with Decision-Making Authority in the Absence of A Statute or Rule" Family Court Review, 53, 578-588.

8. Salimin, N., Jani, J., Ishak, N. A., Hassan, S., Elumalai, G., Boon, O. K., \& Shahril, M. I. (2014). Validity and Reliability Of Comprehensive Assessment Instruments For Professional Skills In Field And Court Sport Among Major Students Coaching Based On Model K.

9. Uzonwanne, F. (2015) "Leadership styles and decision-making models among corporate leaders in nonprofit organisations in North America" Journal of Public Affairs, 287-299.

10. Al radee, hasan (2017): "The Economy of the Gaza Strip: A Decade of Decline, Crisis and Treatment Mechanisms", published study, Birzeit Institute for Development, Project for Development Alternatives in Palestine, Ramallah, Palestine.

11. Samuelson, Paul, Nordhaus, William (2006): "Economy", second edition, Al-Ahlia Publishers and Publishers, Amman, Jordan.

12. Kashkash, Khalid (2014): "Intellectual Capital Management and its Relation to Enhancing Competitive Advantage: An Empirical Study on Palestinian Universities in the Gaza Strip", Master Thesis in Business Administration, Al-Azhar University, Gaza, Palestine.

13. Al Masri, Bilal (2016): "Malaysia's Experience in Economic Development: Lessons Learned", Master Thesis, Al-Azhar University, Gaza, Palestine.

14. Khatoon, N. (2015). Emotional stability, self professional development and its role in effective teaching. International Journal of Business and General Management, 4, 9-14. 
